\title{
Food security through homestead vegetable production in the smallholder agricultural improvement project (SAIP) area
}

\author{
F.M.M. Rahman ${ }^{1}$, M.G.G. Mortuza ${ }^{2}$ M.T. Rahman ${ }^{2}$ and M. Rokonuzzaman ${ }^{3}$ \\ ${ }^{1}$ Department of Agricultural Extension and Rural Development, Bangabandhu Sheikh Mujibur Rahman \\ Agricultural University, Salna, Gazipur-1706, ${ }^{2}$ Cotton Development Board, Dhaka Zone, Farmgate, \\ Dhaka-1215 and ${ }^{3}$ Chittagong Veterinary and Animal Sciences University, Khulshi, Chittagong-4202
}

\begin{abstract}
The purpose of the study was to determine food security through homestead vegetable production. The study was conducted in the Bhaluka, Trishal and Gaforgaon upazilas of Mymensingh district, which were the project areas of the Smallholder Agricultural Improvement Project (SAIP). Sixty (60) respondents were randomly selected from the beneficiaries of SAIP. Data were collected by face-toface interview with the help of interview schedule. Most of the respondents were middle-aged having small farm size and primary level education. Vegetable production, consumption and calorie uptake of the respondent were increased by $56 \%, 55 \%$ and $68 \%$, respectively, after implementation of demonstration. All the respondents are following the 'Kalikapur' model. Nutrient contribution from the produced vegetables through homestead vegetable production fulfilled the $100 \%$ Recommended Dietary Allowance (RDA) requirements of vitamin A, vitamin C, and iron, also $87 \%$ of calcium and $47 \%$ of protein. Four vegetable crops i.e. red amaranth, cabbage, tomato and batishak were introduced into the existing cropping pattern. Changes in social and livelihood issues of a respondent were satisfactory after demonstration. Majority of the respondents (45\%) earned satisfactory annual income having homestead. Shortage of irrigation water, quality seeds and inputs cost were the major problems faced by the farmers in homestead vegetable production.
\end{abstract}

Keywords: Food Security, Homestead vegetables

\section{Introduction}

Bangladesh is a small deltaic country with a population of 132.9 millions with an area of 1 , 47,570 square kilometers (BBS, 2005). Population is roughly divided in to equal percentage of men and women. Bangladesh has about 12 million farm households of which 3.8 millions are landless and marginal (BBS, 1999). Landless and marginal farmers are the most disadvantaged and vulnerable group suffering from insecurity of food and nutrition. The main cause of malnutrition is low availability and consumption of vegetables. In Bangladesh per capita vegetable consumption is only $28 \mathrm{gm}$ as against the daily requirement of $200 \mathrm{~g}$ (Chadha, et al., 1994). Including potato and sweet potato is only about $70 \mathrm{~g}$. More than 30,000 infants become blind every year due to vitamin A deficiency. This situation aggravates when any natural disaster occurs in any area.

Approximately $5 \%$ area $(0.45$ million ha) of total 8.4 million hectares of cultivable land is occupied by homesteads. The size of homestead ranged from 0.027 ha in flood plain area to 0.031ha in char land (BBS 1999). Actual area of homestead devoted to vegetable gardening is very small. Hussein et al., (1988) reported that about $13 \%$ of total homestead area was under vegetable production. Landless and marginal farmers have no or very small crop field. Usually they are maintaining their livelihood by utilizing the homestead and selling of labor. The year round selling of labor is not evenly distributed. Potentiality of labor selling in agriculture is minimum in the rainy season and off-season when they suffer more malnutrition. Considering the importance of vegetable in alleviating the problem of micronutrient deficiencies and in view of the need to increase the production of vegetables by 
all possible means some research activities were initiated by BARI during the early eighties to find out ways to boost vegetable production in the homesteads. The idea was to develop an intensive system of production by which small families can get sufficient nutritious vegetable throughout the year and thereby ensure the supply of needed micronutrients for the family members. The Smallholder Agricultural Improvement Project (SAIP) is one of the projects which were also involved in homestead vegetable gardening. In the context of ever increasing problems of malnutrition and smaller farm size for field crops production, the only feasible option for farm households is to grow vegetables intensively in the homestead, which can provide household food security. Above view of point, the specific objectives of the study entitled "Food Security through Homestead Vegetable Production in the Smallholder Agricultural Improvement Project Area" were: to know the socioeconomic condition of farmers and their present vegetable production status; to identify the impact of homestead vegetable production for food and nutritional security; and to identify problems in homestead vegetable gardening.

\section{Materials and Methods}

The purpose of the study was to determine food security through homestead vegetable production. The study was conducted in the Bhaluka, Trishal and Gaforgaon upazilas of Mymensingh district, which was a project area of the Smallholder Agricultural Improvement Project (SAIP). A list of the home gardening demonstration farmers of study area was prepared with the help of Upazila Agricultural Officers (UAO) and Field Monitoring Officers (FMO) of the SAIP concerned area. All the listed demonstration farmers constituted the population of the study. From the listed 101 demonstration farmers, 60 farmers were selected as sample following random sampling technique. Data were collected by face-to-face interview with the help of interview schedule during the February 25 to March 25, 2007. The interview schedule contained both open and closed form questions. Appropriate scales were also developed to operationalize the selected characteristics which were: age, education, family size, farm size, annual income, and extension media contact. Homestead vegetable gardening were discussed under following sub-head, which were: homestead areas and its utilization; vegetables grown in homestead; utilization of vegetable; average vegetable and rice consumption; per day vegetable consumption and calorie distribution; nutrient contribution from homestead vegetable gardening; changes in social and livelihood issues; vegetable consumption; and family members' participation. Problems faced by farmers in homestead vegetable gardening were identified and also determine its extent as greatly, moderately, partially and not at all (Huda, 2006). The statistical measures as number, percentage, mean, standard deviation use in describing the variables.

\section{Results and Discussion}

\section{Demographic characteristics of the farmers}

The individual characteristics of farmers shown in Table 1.

The farmers ranged in age from 18 to 50 years and the average age was 34.17 years. The highest proportion (50\%) of the respondents was in middle-aged groups as compared to $9 \%$ who were old and $21 \%$ of the respondents were young (Table 1). Educational scores ranged from no formal education to Secondary with an average of 4.67 years of them $59 \%$ respondent had primary level education and 33\% respondent had secondary level education, compared to 8 illiterate. It is very important to note that most of the respondents $(91.66 \%)$ were educated. The family size of the respondents raged from 2 to 7 with an average size was 4.38 . The highest proportion $53.3 \%$ of the respondents had medium family size while $43.3 \%$ of the respondents had small and $3.3 \%$ had large family sized categories (Table 1 ). 
Rahman et al.

Table 1. Distribution of selected characteristics of the farmer

\begin{tabular}{|c|c|c|c|c|c|c|c|c|}
\hline \multirow[b]{2}{*}{ Characteristics } & \multirow{2}{*}{ 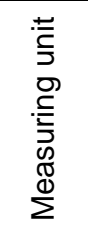 } & \multicolumn{2}{|c|}{ Range } & \multirow[b]{2}{*}{ Categories } & \multicolumn{2}{|c|}{ Growers } & \multirow[b]{2}{*}{ Mean } & \multirow[b]{2}{*}{ SD } \\
\hline & & $\begin{array}{l}\frac{1}{0} \\
\frac{0}{5} \\
0 \\
0\end{array}$ & $\begin{array}{l}\frac{\bar{d}}{2} \\
\overline{0} \\
\mathscr{0} \\
0\end{array}$ & & $\begin{array}{c}\text { Number } \\
(\mathrm{N}=60)\end{array}$ & $\begin{array}{c}\text { Percent } \\
(\%)\end{array}$ & & \\
\hline \multirow{3}{*}{ Age } & \multirow{3}{*}{ 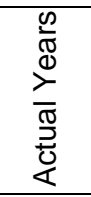 } & \multirow{3}{*}{$\begin{array}{l}\frac{5}{3} \\
\frac{0}{5} \\
\frac{5}{5}\end{array}$} & \multirow{3}{*}{$\begin{array}{l}0 \\
10 \\
1 \\
\infty \\
+1\end{array}$} & Young aged (up to 30) & 21 & 35.0 & \multirow{3}{*}{34.17} & \multirow{3}{*}{9.53} \\
\hline & & & & Middle aged (31-50) & 30 & 50.0 & & \\
\hline & & & & Old $(>50)$ & 9 & 15.0 & & \\
\hline \multirow{3}{*}{ Education } & \multirow{3}{*}{ 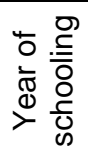 } & \multirow{3}{*}{$\begin{array}{l}\frac{5}{3} \\
\frac{c}{\Sigma} \\
\frac{1}{5} \\
\end{array}$} & \multirow{3}{*}{$\begin{array}{l}0 \\
+1 \\
0\end{array}$} & Illiterate (0) & 5 & 8.0 & \multirow{3}{*}{4.71} & \multirow{3}{*}{1.25} \\
\hline & & & & Primary (1-5) & 35 & 59.0 & & \\
\hline & & & & Secondary (6-10) & 20 & 33.0 & & \\
\hline \multirow{3}{*}{ Family size } & \multirow{3}{*}{ 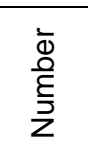 } & \multirow{3}{*}{ 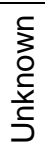 } & \multirow{3}{*}{ 엄 } & Small (up to 4) & 26 & 43.3 & \multirow{3}{*}{4.38} & \multirow{3}{*}{1.44} \\
\hline & & & & Medium (5 to 6) & 32 & 53.3 & & \\
\hline & & & & Large (7 and above) & 2 & 3.3 & & \\
\hline \multirow{4}{*}{ Farm size } & \multirow{4}{*}{ 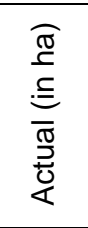 } & \multirow{4}{*}{$\begin{array}{l}\frac{5}{3} \\
0 \\
\frac{1}{5} \\
\frac{5}{J}\end{array}$} & \multirow{4}{*}{ 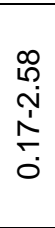 } & Marginal $(<.02)$ & 0 & 0 & \multirow{4}{*}{0.72} & \multirow{4}{*}{0.20} \\
\hline & & & & Small (>.02 to 0.99) & 53 & 88.3 & & \\
\hline & & & & Medium (1-2.99) & 7 & 11.7 & & \\
\hline & & & & Large (3.00 and above) & 0 & 0 & & \\
\hline \multirow{3}{*}{ Annual income } & \multirow{3}{*}{$\begin{array}{l}\frac{\widetilde{\sigma}}{\sigma} \\
\stackrel{\leftarrow}{\leftarrow}\end{array}$} & \multirow{3}{*}{$\begin{array}{l}\frac{5}{3} \\
\frac{c}{\bar{c}} \\
\frac{\mathbf{c}}{5}\end{array}$} & 8 & Low (up to 55,000 taka) & 19 & 31.7 & & \\
\hline & & & $\begin{array}{l}\text { ý } \\
\text { Ṅ } \\
0\end{array}$ & Medium $(55,001-70,000)$ & 14 & 23.3 & 6.06 & 1.09 \\
\hline & & & ? & High (70,001 and above) & 27 & 45 & & \\
\hline & ఖ & & $\varphi$ & Low (up to 18) & 26 & 43.3 & & \\
\hline contact & రัँ & f̛ & m̧ & Medium (>18-20) & 23 & 38.3 & 19.18 & 2.0 \\
\hline & ஸ & & & High ( above 20) & 11 & 18.3 & & \\
\hline
\end{tabular}

The highest proportion $88.3 \%$ had small farm size rest of the $11.7 \%$ had medium farm size. The average farm size was 0.72 ha. Most of the respondents (45\%) were in high income as compared to $23.3 \%$ medium income and $31.7 \%$ low income respectively. The computed scores of the respondents based on extension contact score of the respondents ranged from 16 to 24 and the mean score was 19.18. Most of the respondents had low (43.3\%) communication exposure followed by medium (38.3\%) and high (18.3\%) communication respectively (Table 1$)$.

\section{Homestead vegetable gardening}

The respondents have been followed traditional system before SAIP involvement. But after involvement cent percent respondents were followed 'Kalikapur' model and traditional practice. Different important subject matters related to homestead vegetable gardening were identified for proper investigation of the study. These matters were discussed in this section under the following sub-heads. 


\section{Homestead areas and its utilization}

Data presented in the Table 2 revealed that homestead ranged from 5 decimal to 12 decimal with an size of 8 decimal. Before demonstration average area for growing vegetables in homestead was 1.12 decimal which was found 2.5 decimal after demonstration. There was low utilization of homestead compared to average homestead size.

Table 2. Homestead area and its utilization by the respondents

\begin{tabular}{|c|c|c|c|c|c|}
\hline \multicolumn{2}{|c|}{ Homestead and utilization } & $\begin{array}{c}\text { Maximum size } \\
\text { (decimal) }\end{array}$ & $\begin{array}{c}\text { Minimum } \\
\text { size (decimal) }\end{array}$ & Mean & $\begin{array}{l}\text { Standard } \\
\text { deviation }\end{array}$ \\
\hline \multicolumn{2}{|c|}{ Total area under homestead } & 12 & 5 & 8 & 2.23 \\
\hline \multirow{2}{*}{$\begin{array}{l}\text { Area for } \\
\text { growing } \\
\text { vegetable }\end{array}$} & \begin{tabular}{|l} 
Before \\
demonstration
\end{tabular} & 2 & 1 & 1.12 & 0.29 \\
\hline & $\begin{array}{l}\text { After } \\
\text { demonstration }\end{array}$ & 3 & 2 & 2.5 & 0.44 \\
\hline
\end{tabular}

The respondents have followed traditional system before demonstration but after demonstration they followed 'Kalikapur model' and traditional system in the homestead vegetable production. On an average size of home garden kalikapur model was 1.0 decimal. They also used other micro sites of their homestead in traditional practice.

\section{Vegetables grown in homestead}

Before demonstration respondent cultivates 9 different vegetables such as radish, brinjal, amaranth, spinach, bitter gourd, sweetgourd/bottle gourd, lady's finger and bean. But after demonstration they had grown 13 items on the basis of kalikapur model. These were red amaranth, radish, brinjal, cabbage, tomato, amaranth, spinach, batishak, bittergourd, lady's finger, bottle gourd, sweet gourd and bean in winter and summer season. Radish, brinjal and spinach were very much popular in both 'before- after' conditions. Red amaranth, cabbage, batishak, tomato and HYV bean were introduced after the project. Average vegetable production in the home garden was $116 \mathrm{~kg}$ and $202 \mathrm{~kg}$ at 'before 'and 'after' respectively (Table 3).

Table 3. Distribution of different vegetables grown in homestead

\begin{tabular}{|c|c|c|c|c|}
\hline \multirow[t]{2}{*}{ Vegetables } & \multicolumn{4}{|c|}{ Grown in homestead } \\
\hline & \multicolumn{2}{|c|}{ Before } & \multicolumn{2}{|c|}{ After } \\
\hline Winter & Area (deci) & Production $(\mathrm{kg})$ & Area (deci) & Production $(\mathrm{kg})$ \\
\hline Red amaranth & 0 & 0 & .2 & 13 \\
\hline Radish & .4 & 19 & .3 & 22 \\
\hline Brinjal & .4 & 25 & .5 & 32 \\
\hline Cabbage & 0 & 0 & .2 & 14 \\
\hline Tomato & 0 & 0 & .2 & 10 \\
\hline Stem amaranth & .2 & 11 & .3 & 17 \\
\hline Bottle gourd & .1 & 8 & .2 & 12 \\
\hline Bean & Fence & 7 & Fence & 10 \\
\hline \multicolumn{5}{|l|}{ Summer } \\
\hline Spinach & .5 & 20 & .5 & 30 \\
\hline Batishak & 0 & 0 & .2 & 11 \\
\hline Bitter gourd & .2 & 4 & .3 & 9 \\
\hline Lady's finger & .3 & 8 & .3 & 12 \\
\hline Sweet gourd & .1 & 10 & .1 & 10 \\
\hline Total & - & 116 & - & 202 \\
\hline
\end{tabular}




\section{Utilization of vegetables}

From the Fig. 1. it was found that $74 \mathrm{~kg}$ and $113 \mathrm{~kg}$ out of $116 \mathrm{~kg}$ and $202 \mathrm{~kg}$ vegetables utilized as own consumption in both before and after condition respectively. Maximum amount of produced vegetables $(74 \mathrm{~kg}$ and $113 \mathrm{~kg})$ used as own consumption purpose in both before and after demonstration (Fig 1.). Average sold of vegetables by the respondents in before and after demonstration was $30 \mathrm{~kg}$ and $56 \mathrm{~kg}$ and also their distribution was $12 \mathrm{~kg}$ and $13 \mathrm{~kg}$, respectively. It was found that after demonstration average homestead vegetable production increased by $74 \%$.

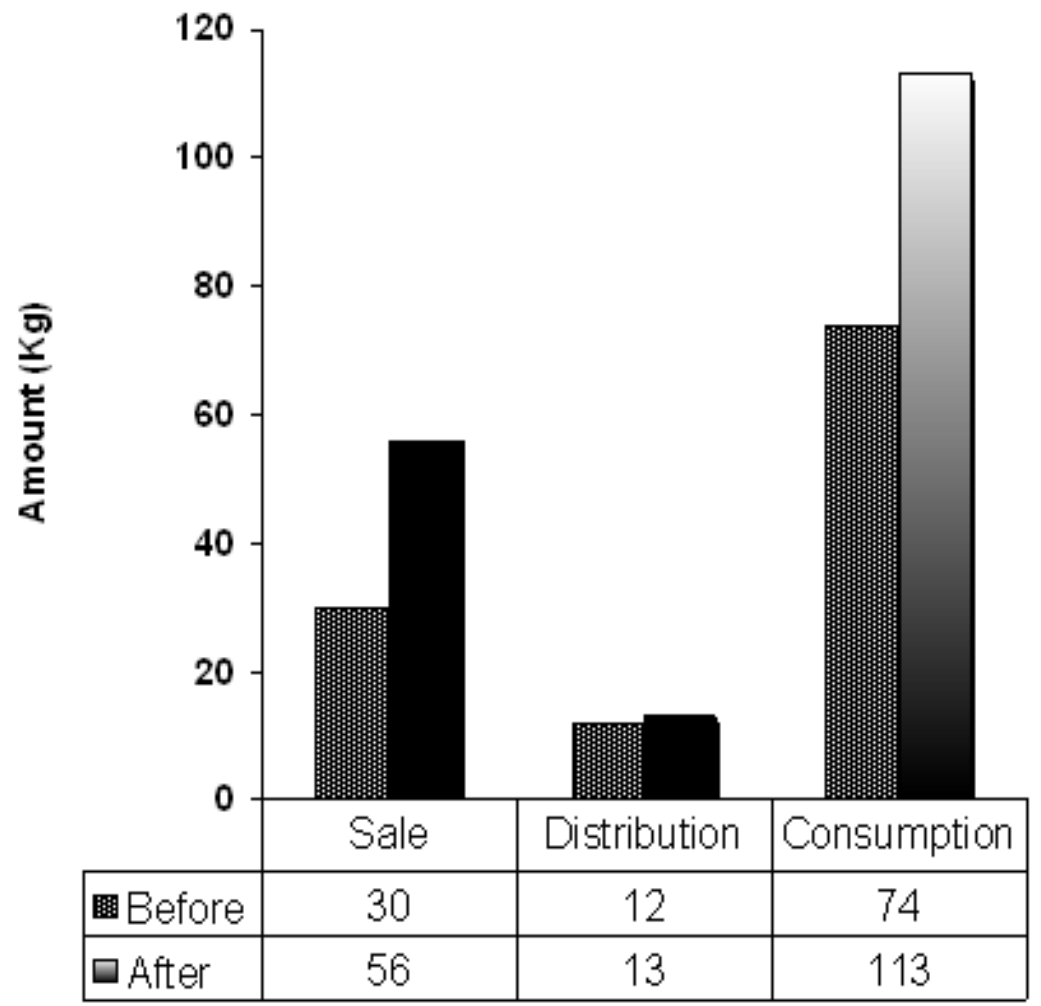

Fig 1. Bar graph showing comparison of vegetable utilization

\section{Average vegetable and rice consumption}

Consumption of rice and vegetable are very important for food and nutrition. Only cereals or vegetables cannot fulfill the requirements of balance food. Vegetables can improve the nutritional value of other food items. It was observed that (Table 4.) the respondents' average vegetable consumption increased from $46 \mathrm{~g}$ to $83 \mathrm{~g}$ after homestead vegetable gardening i.e. consumption increased by $80 \%$. At the same time per day rice consumption changed from $475 \mathrm{~g}$ to $411 \mathrm{~g}$ i.e. rice consumption decreased $13 \%$. It is interesting to note that after homestead vegetable demonstration respondents' vegetable consumption increased but their rice consumption decreased. It might be increased due to awareness about balance food and vegetable consumption. 
Table 4. Average changes in rice and vegetable consumption

\begin{tabular}{|l|c|c|c|}
\hline \multirow{2}{*}{ Items } & \multicolumn{2}{|c|}{ Consumption per day/person (g) } & \multirow{2}{*}{ Amount change (g) } \\
\cline { 2 - 3 } & Before & After & \\
\hline Vegetables & 46 & 83 & 37 \\
\hline Rice & 475 & 411 & $(-) 64$ \\
\hline
\end{tabular}

Per day vegetable consumption and calorie distribution

Vegetables are important sources of vitamins and minerals in the diet. Fruits and vegetables serve the same nutritional purpose, but vegetables are much easier and cheaper to produce. Moreover, vegetables are generally able to produce more nutrients per unit time. The National Nutrition Council of Bangladesh (BNNC) has proposed for the country a balanced diet in the recommended quantity of vegetables including tubers and spices is $235 \mathrm{grams}$ per head per day (root crops-100gm+leafy vegetables-125gm+spices-10gm). The respondents mainly produced leafy vegetables in the home garden and they consumed maximum amount of vegetables for improving their food and nutritional status. Food and nutritional status of different vegetables were measured with the help of nutritional value index. Calculated amount of calorie uptake from different vegetables were presented in Table 5 . Before demonstration over all per day vegetable production was $318 \mathrm{~g}$ and after demonstration it was $553 \mathrm{~g}$. Per day consumption was $202 \mathrm{~g}$ and $364 \mathrm{~g}$ in before and after demonstration, respectively. It was observed that (Table 5) production and consumption increased in both the cases. Total calorie uptake from different consumed vegetable was 73.0 k.cal. and 111.0 k.cal.in the before after condition, respectively. Calorie uptake was also increased by 38.0 k.calorie after demonstration. It was found that after demonstration average vegetable consumption and calorie uptake were increased near to fulfilled the recommendation.

Table 5. Average vegetable production, consumption and calorie contribution

\begin{tabular}{|l|c|c|c|}
\hline $\begin{array}{l}\text { Homestead vegetable } \\
\text { gardening }\end{array}$ & $\begin{array}{c}\text { Production } \\
(\mathrm{g}) / \text { day }\end{array}$ & $\begin{array}{c}\text { Consumption } \\
(\mathrm{g}) / \text { day }\end{array}$ & $\begin{array}{c}\text { Calorie uptake } \\
\text { (K.cal)/day }\end{array}$ \\
\hline Before demonstration & 318 & 202 & 73 \\
\hline After demonstration & 553 & 364 & 111 \\
\hline Amount change & 235 & 162 & 38 \\
\hline
\end{tabular}

\section{Nutrient contribution from homestead vegetable gardening}

Vegetables are the important source of essential nutrients for human. Particularly leafy vegetables are rich in these nutrients. In the homestead vegetable gardening, respondents were grown 13 different kinds of leaf oriented vegetables. Different essential nutrient contribution from these vegetables were presented in Table 6. Nutritional values of different vegetables were calculated according to Islam et al., (2003) with the help of nutritional value index. It was found that different essential nutrients such as protein, vitamin A, Vitamin C, calcium and iron contribution from different vegetables increased after homestead vegetable gardening. In consideration to Recommended Dietary Allowance (RDA), the vegetables grown in home garden fulfilled the $100 \%$ requirement of vitamin A, vitamin C, and iron. It also fulfilled $47 \%$ of protein and $87 \%$ of calcium requirement. Vegetables are not rich in protein but improve the protein nutrition status if taken with the cereals and pulses. Table 6 , showed that selected essential nutrient contribution was changed significantly after demonstration. 
Table 6. Changes in nutritional status through homestead vegetable production

\begin{tabular}{|l|c|c|c|c|c|c|c|c|c|c|c|c|}
\hline \multirow{2}{*}{} & \multicolumn{2}{|c|}{$\begin{array}{c}\text { Edible yield/ } \\
\text { day }(\mathrm{g})\end{array}$} & \multicolumn{10}{|c|}{ Nutrient yield/day } \\
\cline { 2 - 15 } & Before & After & Before & After & Before & After & Before & After & Before & After & Before & After \\
\hline & 318 & 553 & 49.28 & 70.14 & 51223 & 95312 & 1607 & 2914 & 1450 & 2689 & 122 & 210 \\
\hline RDA & & & 149 & 149 & 2625 & 2625 & 140 & 140 & 3100 & 3100 & 49 & 49 \\
\hline $\begin{array}{l}\text { \% Of RDA } \\
\text { contribution }\end{array}$ & & & 33.1 & 47.1 & 1951.4 & 3630.9 & 1147.9 & 2081.4 & 46.8 & 86.7 & 249.0 & 428.6 \\
\hline
\end{tabular}

\section{Changes in social and livelihood issues}

Social and livelihood issues of respondents are very important factor. Homstead vegetable production can play an important role in changing social and livelihood issues. As shown in Table 7, overall change is observed in some selected social and livelihood issues. Regarding issue-wise changes, vegetable consumption and 'use of biological control' changed partially to greatly; 'contact with extension workers', 'homestead land use pattern' and 'opportunity of income generating activities' were changed partially to moderately; and contact with NGO workers changed from moderately to greatly. Islam and Ahmad(2004), also observed some change in social and livelihood issues.

Table 7. Social and livelihood issues changes in different aspect of respondents

\begin{tabular}{|l|l|l|}
\hline \multirow{2}{*}{ Aspects of change } & \multicolumn{2}{|c|}{ Extent of change } \\
\cline { 2 - 3 } & Before & After \\
\hline Vegetable consumption & Partially & Greatly \\
\hline Change of Homestead land use pattern & Partially & Moderately \\
\hline Contact with extension workers, GO & Partially & Moderately \\
\hline Contact with extension workers NGO & Moderately & Greatly \\
\hline Biological control (IPM) & Partially & Greatly \\
\hline Opportunity of income generating activities & Partially & Moderately \\
\hline
\end{tabular}

\section{Vegetable consumption}

The respondents produced sufficient amount of vegetables but their consumption was not satisfactory. They mentioned that large amount of vegetables were sold to minimize other family needs, and disliking to eat vegetables everyday due to previous habit were the major causes of low vegetable consumption.

\section{Family members' participation}

Home garden is mostly managed by the idle family labor of men women and children. Male members of a family always play a vital role in most of the family affairs but female and child labor were unutilized or neglected. Data presented in Table 8, revealed that after demonstration participation of male in different homestead vegetable production activities decreased from $61 \%$ to $47 \%$ but participation of female members and children were increased from $32 \%$ to $41 \%$ and $7 \%$ to $12 \%$, respectively. As a result, the saved male labor could be utilized in other income generating activities. 
Table 8. Participation of family members in different operations

\begin{tabular}{|l|c|c|c|c|c|c|}
\hline \multirow{3}{*}{ Operations } & \multicolumn{6}{|c|}{ Members } \\
\cline { 2 - 7 } & \multicolumn{2}{|c|}{ Male( in percent) } & Female(in percent) & \multicolumn{2}{c|}{ Child(in percent) } \\
\cline { 2 - 7 } & Before & After & Before & After & Before & After \\
\hline Land preparation & 66 & 50 & 27 & 38 & 7 & 12 \\
\hline Planting & 63 & 49 & 31 & 40 & 6 & 11 \\
\hline Weeding & 62 & 47 & 30 & 40 & 7 & 12 \\
\hline Mulching & 59 & 47 & 34 & 41 & 7 & 12 \\
\hline Irritation & 55 & 45 & 36 & 42 & 9 & 13 \\
\hline Stalking & 58 & 46 & 36 & 43 & 6 & 11 \\
\hline Fencing & 67 & 50 & 30 & 42 & 3 & 8 \\
\hline Harvesting & 54 & 42 & 37 & 42 & 9 & 14 \\
\hline Plant protection & 66 & 47 & 30 & 43 & 4 & 9 \\
\hline All & $\mathbf{6 1}$ & $\mathbf{4 7}$ & $\mathbf{3 2}$ & $\mathbf{4 1}$ & $\mathbf{7}$ & $\mathbf{1 2}$ \\
\hline
\end{tabular}

Table 9. Problems faced in homestead vegetable production

\begin{tabular}{|l|c|c|c|c|}
\hline \multirow{2}{*}{ Problems } & \multicolumn{4}{|c|}{ Severity of problems (\%) } \\
\cline { 2 - 5 } & Greatly & Moderately & Partially & Not at all \\
\hline Shortage of irrigation water in dry season & 66.7 & 25.0 & 8.3 & 0.0 \\
\hline Lack of quality seed & 51.7 & 33.3 & 8.3 & 6.7 \\
\hline Cost of input & 46.7 & 28.3 & 16.7 & 8.3 \\
\hline Damage by poultry \& livestock & 40.0 & 38.3 & 13.3 & 8.3 \\
\hline Lack of storage facility & 36.7 & 40.0 & 16.7 & 6.7 \\
\hline Lack of marketing facility & 30.0 & 51.7 & 15.0 & 3.3 \\
\hline Lack of capital & 25.0 & 46.7 & 16.7 & 11.7 \\
\hline Lack of technical knowledge & 23.3 & 53.3 & 13.3 & 10.0 \\
\hline Insect pest attack & 16.7 & 40.0 & 33.3 & 10.0 \\
\hline Food habit & 3.3 & 63.3 & 8.3 & 25.0 \\
\hline
\end{tabular}

It was found that most of the respondent indicated "shortage of irrigation water in dry season" a highest problem. Actually irrigation was the most important factor for cultivation of vegetable, in the Rabi season. Irrigation of vegetable in homegarden is possible by water supply from tube well and shallow tube wells or other sources. In the study area most of the respondent's household is in high land and in dry season draw down water level. Then maximum tube well gone out of order. So they faced severe problem in irrigation problem. Lack of quality seed was identified as another major problem. Farmers always need high quality vegetable seeds, because they have lack of technical knowledge on quality seed production and seed preservation. Sometimes they lost their money and crops because of buying low quality seeds.

High input cost was identified as another major problem. Farmers need to purchase required inputs. Sometime input dealers and agencies cheat the farmers by taking high price for inputs. Poultry and livestock were identified as a problem in homestead vegetable gardening. Poultry and livestock damaged vegetables. So home gardening needs protections and sometimes it is too expensive. Lack of storage facility was also a problem. Sometimes respondents produced excess vegetable, which they could not consume. So large amount of vegetable were in wastage loss. Respondents had no technical knowledge of preservation. 
Lack of marketing facility was another problem. Respondents sold their vegetable in the local market due to communication facilities .So they did not got good price. Lack of capital was a problem of the study area. Respondents initially need financial support to establish a home garden. Lack of technical knowledge on vegetable production and preservation, insect / pest attack on vegetables and consuming vegetable as food were identified as problem.

\section{References}

BBS. 1999. Statistical Year Book of Bangladesh. Bangladesh Bureau of Statistics, Ministry of Planning, Government of the People's Republic of Bangladesh.

BBS. 2005. Census of Agriculture. 1996. Bangladesh Bureau of Statistics, Ministry of Planning, Government of the People's Republic of Bangladesh.

Chadha, M.L.S., Shanmugassundram, A.K.M.A. Hossain and Hossain, S.M. 1994. Vegetable Research and Development in Bangladesh, BARI, Gazipur

Huda,M.Z. 2006. Farmers Response to Modern Maize Cultivation in Kapasia Upazila of Gazipur District. An Unpublished MS (AER). Thesis, Department of Agricultural Extension and Rural Development, Bangabandhu Sheikh Mujibur Rahman Agricultural University, Salna, Gazipur.

Hussein, M.S., Abedin, M.Z., Quddus, M.A. and Ahmed, D. 1988. Women's Contribution to Homestead Agriculture Production System in Bangladesh. Bangladesh Academy for Rural Development, Comilla. Pp.344.

Islam, M.F., Ali, A.A. and Asraf, A. 2003. Homestead Vegetable Gardening: A Means of Household Food and Nutritional Security for Marginal Farmer. Bangladesh Journal of Agricultural Research, 28 (2): 261- 270.

Islam, M.S. and Ahmed, S. 2004. Daridro Bimochone Samonnito Khamar Unnayon Krishi Projukti. (Livelihood Research Development,) OFRD, BARI, West Goalchamot, Faridpur. 